\title{
Dropping the Curtain: The Religious- Secular Party Cleavage in German Morality Politics
}

\author{
Eva-Maria Euchner \\ Ludwig-Maximilians-Universität München \\ Caroline Preidel \\ Coliquio, Germany
}

\begin{abstract}
This study examines the religious-secular party cleavage in German morality politics from a new perspective by tracing politicization patterns at the individual level. It builds on the idea of issue competition and explores whether conflicts between Christian Democrats and secular parties align with the traditional denominational divide between Catholics and non-Catholics or with religiosity. By means of logistic regressions of Member of Parliaments' politicization behavior in the German Bundestag (1998-2002) with regard to three morality policies, the study provides evidence that German politics is still structured by a conflict between Catholics and non-Catholics, whereas the influence of religiosity is secondary. If party competition is at work, nonCatholics draw attention to morality policies, while Catholics refrain from doing so. This finding contradicts research pointing to a decreasing significance of Catholicism for Christian Democracy. Moreover, the study proposes an innovative way to re-examine party cleavages at the individual level and in between elections.
\end{abstract}

Address correspondence and reprint requests to: Eva-Maria Euchner, Geschwister-Scholl-Institut für Politikwissenschaften, Ludwig-Maximilians-Universität München, Oettingenstr. 67, DE-80538 Munich, Germany. E-mail: eva-maria.euchner@gsi.lmu.de.

This article is part of the research project MORAPOL (Comparative Analysis of Moral Policy Change), funded by the European Research Council Advanced Grant (Grant No. 249388) and led by Professor Christoph Knill (Ludwig-Maximilians-Universität München). We are very grateful for the comments from our colleagues of the MORAPOL project, Marc Debus (University of Mannheim), Christoffer Green-Pedersen (University of Aarhus), Petra Meier (University of Antwerp), and Mieke Verloo (Radboud University). 


\section{INTRODUCTION}

The seminal work of Engeli, Green-Pedersen, and Larsen (2012) has highlighted the continued importance of the religious-secular party cleavage for the politicization of morality issues in Western Europe. In contrast to other scholarship suggesting the decreasing importance of religion in morality politics (Asal, Sommer, and Harwood 2013; Fink 2008; Knill, Preidel, and Nebel 2014) and the increasingly "unsecular" approach of Christian Democrats (Van Kersbergen 2008), Engeli, Green-Pedersen, and Larsen (2012) argue that the politicization of morality issues non-economic issues that provoke value conflicts - is still structured by the religious-secular cleavage between Christian Democrats and secular parties. In this study, however, we question the "depth," so to speak, of this religious-secular party cleavage in Western Europe and ask what dynamics and divides actually shape the cleavage today? ${ }^{1} \mathrm{We}$ raise this question in light of the modernization of Christian Democratic parties, their increasing departure from Catholic teachings (Clemens 2009; Debus and Müller 2013), the growing distance between religious voters and Christian Democratic parties (Elff 2013), and the decreasing power of traditional cleavages to explain the political behavior of citizens and political elites (Evans 1999; Kriesi 1998; 2010). More specifically, we ask whether the cleavage between Christian Democrats and secular parties still exists in German morality policy and, if so, in what form? Is the denominational divide between Catholics and non-Catholics originally proposed by Lipset and Rokkan (1967) still relevant today or do we find mainly a divide between religious and secular actors in accordance with transformations in citizens' voting behavior (Rapp et al. 2014)?

To answer these questions, this study examines the conflict between individual MPs (Member of Parliaments) vis-à-vis the politicization of morality issues in the German Bundestag. It asks not only whether a religious cleavage is, indeed, still present among German elites, but also what form it takes (i.e., Christian Democratic versus secular parties, Catholics versus non-Catholics, religious MPs versus non-religious MPs). Whereas previous scholarship on changing party cleavages examines citizens' voting behavior, we follow research on legislative behavior and issue competition by exploring instead at individual MPs' initiative behavior on value-loaded policies. ${ }^{2}$ In doing so, we investigate which personal characteristics - i.e., affiliation to the Catholic Church or religiosity - unify the parliamentary actors of different conflict coalitions during the policy initiation and formulation stage. This micro-level 
perspective on parliamentary behavior is very innovative because it enables us to open the "black box" of political parties, regularly seen as monolith collective actors, and to explore the actual existence and fundament of religious-secular party cleavages on the ground. Aside from this innovative methodological approach, the new analytical angle allows us to evaluate cleavage structures in between elections - a rare insight that complements existing studies focusing on voting behavior. Not only religious-secular divides but any other party cleavage proposed by Lipset and Rokkan (1967) can be re-evaluated in between elections through this fresh perspective on parliamentary behavior.

Analyzing individual politicization behavior in the German Bundestag with regard to the regulation of gay marriage, prostitution, and stem cell research during the $14^{\text {th }}$ legislative term offers a valuable empirical window onto the complex dynamics of competition among religious and secular parties in the context of morally-loaded conflicts. The German party system is seemingly organized by a religious cleavage, with two Christian Democratic Parties - the Christian Democratic Union (CDU) and the Christian Social Union (CSU) - competing with four secular parties. Moreover, the Christian Democratic Union is electorally relatively successful and could well maintain its standing as the most powerful party in Germany, in contrast to its counterparts in other European countries (Bale and Krouwel 2013). As such, Germany offers a strong case for examining our research questions.

Briefly, we find that German party competition on morality policies is still structured by a religious-secular cleavage, meaning a divide between Christian Democrats and secular parties. At the micro-level, however, we observe that it is the conflict between Catholics and non-Catholics, and not necessarily the conflict between religious and non-religious deputies, which shapes politicization behavior. In contrast to scholars who argue that the traditional religious cleavage has lost relevance as Christian Democrats drift from their Catholic roots, we find that parliamentary behavior on morality issues continues to be structured by the cleavage between the Catholic Church and the nation-state as originally conceptualized by Lipset and Rokkan (1967). Specifically, we observe that German Catholic MPs avoid politicizing morality issues, while non-Catholics strive to put morality issues on the parliamentary agenda. If party discipline is relaxed, the divide between Catholics and non-Catholics still structures parliamentary behavior, but Catholics do not stay passive but instead engage actively in suggesting restrictive policy solutions. In short, although Engeli, Green-Pedersen, and Larsen's (2012) argument 
regarding a religious-secular cleavage finds surface-level support in Germany, once we look at the micro-level, we find that the divide between Catholics and non-Catholics better explains individual MPs' behavior when it comes to the politicization of morality issues.

The article is structured as follows: After introducing the research on party cleavage structures and morality issues, we outline the theoretical framework and central expectations, and then explain the research design. Next, we present and discuss the empirical results regarding the conflict structures of morality policies. Finally, we conclude with a summary and discussion of the empirical findings.

\section{THE RELIGIOUS-SECULAR CLEAVAGE AND MORALITY ISSUES}

Morality issues are characterized by value conflicts over "first principles," as opposed to issues defined by monetary values. Popular examples are the regulation of abortion, stem cell research, prostitution, and same-sex partnerships (Heichel, Knill, and Schmitt 2013; Meier 1994; Mooney 2001). When debating these questions, religious doctrines offer an important source of value orientation for political parties and individual MPs. Thus, it is assumed that morality politics will be organized along religious lines. As noted above, the work of Engeli, Green-Pedersen, and Larsen (2012) aims to explain the different levels of politicization of morality issues in Western Europe, using the existence or non-existence of a religious-secular party cleavage in a country as the explanatory variable. By reactivating party cleavage theory in this way, the authors propose a very innovative framework. In line with the work of Budge and Farlie's (1983), ${ }^{3}$ Engeli, Green-Pedersen, and Larsen (2012) argue that Christian Democrats and secular parties compete not only in terms of their specific positions on issues, but also in terms of their emphasis on different issues during as well as in between elections. Regarding morality politics, Engeli, Green-Pedersen, and Larsen (2012) propose that increased levels of issue attention are the product of a religious cleavage between Christian Democratic and secular parties. All countries that possess a strong Christian Democratic or church-associated party are part of the so-called "religious world," while those countries without strong religious parties are categorized as part of the "secular world." In the "religious world," morality policy attention is high because secular parties politicize these issues in order to challenge Christian Democrats and thus, are able to use morality issues along an issue competition logic. 
Yet empirical studies on morality policies, party position transformation, Christian Democracy in modern times, and party cleavages in electoral behavior raise the question of whether the conflict between Christian Democrats and secular parties is still founded on the traditional religious cleavage between Catholics and non-Catholics (Clemens 2009; Elff 2013; Kalyvas and Van Kersbergen 2010). Several researchers argue that Christian Democratic parties, historically grounded on Catholic teachings, have undergone ideological change in order to survive in times of secularization and a shrinking Catholic electorate. Such parties no longer seek to accommodate only Catholics; rather, they now incorporate and address heterogeneous groups within society and adopt a more moderate profile vis-à-vis morality issues, such as abortion, gay marriage, and sexual services (Debus and Müller 2013; Kalyvas and Van Kersbergen 2010; Knill, Preidel, and Nebel 2014). These changes often engender severe struggles within Christian Democratic parties (Kalyvas and Van Kersbergen 2010). These findings are in line with electoral studies that have discovered a decline of the denominational cleavage and emphasized instead the multidimensionality of the religious factor (Kohut 2000). For instance, studies reveal that, despite the reduction of denominational differences, a religious cleavage still exists that splits regular church attendees from non-attendees (Van Der Brug, Hobolt, and de Vreese 2009; Elff 2013; Knutsen 2004). Based on studies that analyze parliamentary voting behavior on morality issues (Preidel 2016), one could expect to find the same divides not only among the electorate of Christian Democratic parties but also among party members themselves in parliament.

In sum, all of these factors - the changing nature of modern Christian Democracy and the non-consideration of the multidimensional character of religion - highlight the need for work on the relevance and conception of the religious-secular cleavage in European morality politics today. The need for clarification increases specifically in the German context when we look at the religious composition of parliamentary party groups in the Bundestag, a parliament featuring a typical divide between Christian Democratic and secular parties. Figure 1 shows how Catholic, Protestant, and religious MPs were distributed across the different parliamentary party groups for the $14^{\text {th }}$ legislative period (1998-2002). It reveals that Christian Democrats in fact include the largest proportion of Catholics (about 70\%). Surprisingly, however, only 50\% of the "very religious" MPs are members of Christian Democratic parties, while the other half are members of secular parties. Even at this descriptive level, then, we 


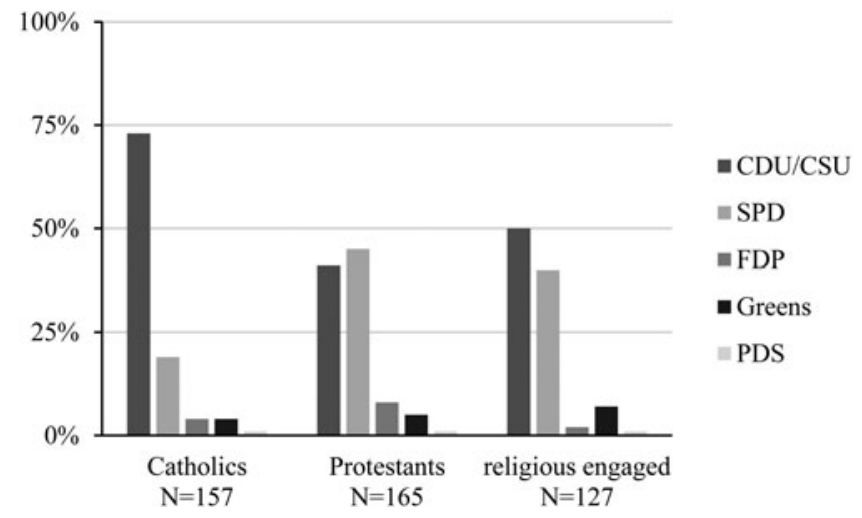

FIGURE 1. Party composition for each religious group in the German Bundestag (1998-2002). Note: Data source: German Bundestag.

find evidence against the claim that religiosity now structures the religious-secular party cleavage; meanwhile, the divide between Catholics versus non-Catholics is more pronounced, but it too fails to align precisely with the divide between Christian Democratic and secular parties

The present study tackles these puzzling patterns. By taking a closer look at the issue competition of German parties on morality policies, we investigate whether a religious-secular cleavage is still present and, if so, in which form (i.e., Christian Democratic versus secular parties, Catholics versus non-Catholics, religious MPs versus non-religious MPs). In this way, we depart from the traditional approach of analyzing party cleavages through the analysis of citizens' voting behavior or the collective position taking of parliamentary party groups during the phases of electoral campaigns and decision-making. Instead, we introduce a new perspective on how to examine the religious-secular party cleavage in morality politics in the parliamentary arena and pre-decision-making stages.

\section{THEORETICAL FRAMEWORK}

To examine the question of the existence and foundations of the religioussecular conflict in German morality policy-making, we integrate Engeli, Green-Pedersen, and Larsen's (2012) argument with the idea of issue competition (Budge and Farlie 1983) and the concept of policy-, 
office-, and vote-seeking (Müller and Strøm 1999). Based on these theoretical approaches, we assume that the salience of morality policy in the German Bundestag is shaped by a conflict between Christian Democrats and secular parties. ${ }^{4}$ At the micro-level, however, the individual (religious) characteristics and interests of MPs are decisive. According to Coleman (2000) and the popular "bathtub model," a micro-foundation is always necessary to explain macro-level phenomena. As such, the micro-level perspective employed in this article is an innovative way to explore party cleavage structures and to test previously proposed macro-level propositions. ${ }^{5}$ We propose three theoretical expectations regarding party and MPs' individual initiative behavior on morality policies dependent on three different aspects of religion (i.e., religious versus secular party membership, Catholicism versus non-Catholicism, religiosity versus non-religiosity). All hypotheses are based on the common assumption that the policy status quo displays a restrictive regulation at the starting point of our examination.

With regard to morality policies, secular political parties are able to pressure religious political opponents by emphasizing morality issues in the parliamentary arena by, for example, sponsoring legislative bills. Such a strategy is successful, according to Engeli, Green-Pedersen, and Larsen (2012), because morality policies are unattractive to religious parties given an increasingly secular voter base. This is particularly true when the religious party seeks to maintain its position as a mass party (Euchner 2015a). In line with Kalyvas and Van Kersbergen (2010), Engeli, Green-Pedersen, and Larsen (2012) suggest religious parties would do best to develop an "unsecular" profile that would enable them to gain support from (new) non-religious voters, while still preserving their religious voter base. In this way, Engeli, Green-Pedersen, and Larsen (2012) indirectly argue that religious parties can integrate policy-, office-, and vote-seeking strategies by not politicizing morality issues. More specifically, Christian Democrats can attract new support without losing their traditional voters; and, at the same time, the restrictive regulatory status quo of morality policies can be contained. We expect single Christian Democratic MPs to follow a similar strategic behavior in terms of morality policies because party discipline is often very strong and individual MPs also aim to enhance their voter base and their political career by challenging their opponents and similarly pushing through their own policy interests (Carey 2009; Kam 2011). We therefore propose: 
Expectation 1a: If an MP is a member in a political party, which is relatively large, has strong religious roots, and is confronted with a secular counterpart, she/he will not politicize morality issues in parliament.

Expectation 1b: If an MP is a member in a political party, which is relatively large, has strong secular roots, and is confronted with a religious counterpart, she/he will politicize morality issues in parliament.

One might question this logic, both at the macro- and the micro-level. First, large religious parties such as the Christian Democrats not only face an increasingly secular voter base, but have also undergone a modernization process in recent years that has produced more progressive policy preferences in regard to morality issues (Debus and Müller 2013; Euchner 2015a; Kalyvas and Van Kersbergen 2010). Second, morality politics have provoked severe value conflicts and, in some cases, divided the members of religious political parties, resulting in different individual political strategies (Baumann, Debus, and Müller 2013; Knill et al. 2015). As such, one can ask whether party competition between religious and secular parties is still in working order? And if so, what does the religious fundament look like? Is party competition between these actors still found on the religiosity of their MPs or does the religious denomination of MPs drives the behavior of partisan actors?

In line with the literature on morality politics, we expect Catholic MPs to avoid politicizing morality issues, while non-Catholics seek to put these issues on the parliamentary agenda. More specifically, MPs without membership in a religious community — so-called non-affiliated MPs — profit from the politicization of morality issues because such issues may mobilize new secular voters and align with the MPs' permissive policy positions regarding morality policies in public. In addition, we expect Protestants to behave differently (and in particular less coherently) than Catholics, as the Catholic Church is organized more hierarchically and formulates more explicitly and uniformly restrictive positions toward morality policies (Willems 2007). For instance, some Protestant priests in Germany blessed homosexual couples in the past, although the main representative organ of the Protestant Church did not allow it. Moreover, even before the German Bundestag permitted civil marriage of homosexual couples in July 2017, the Protestant Church in Rhineland allowed their 
priests to bless same-sex couples. No similar instance is known from any Catholic diocese in Germany. Therefore, we expect the divide between Catholics and non-Catholics to be even more clear-cut than that between Catholics and Protestants or Catholics and non-affiliated MPs. Consequently, we propose:

Expectation 2a: If an MP is Catholic, he/she will not politicize morality issues in parliament.

Expectation 2b: If an MP is non-Catholic, he/she will politicize morality issues in parliament and propose permissive reforms proposals.

Studies on electoral behavior showed that the denominational divide has decreased, while the divide between Christians regularly attending religious services and non-attendees has gained salience (Van Der Brug, Hobolt, and de Vreese 2009; Elff 2013; Knutsen 2004; Rapp et al. 2014). This engagement of Christians in their community, independent of the denomination with which they are affiliated, captures an additional dimension of religion, and may stand behind the religious-secular cleavage at the party level.

We consider MPs who regularly attend church services or are involved in church-associated organizations to be equally active in parliament. Because religious community engagement strengthens and conserves religious beliefs and norms in daily life (Kohut 2000), these MPs are more likely to act in line with religious values and articulate them openly than more passive, uninvolved church members. Active religious MPs may prefer restrictive regulation of morally charged issues and hence, a protection of the regulatory status quo. In order to promote these interests and follow their policy-, vote-, and office-seeking aims, such MPs will not politicize morality issues. Non-religious deputies, by contrast, might politicize morality policies actively in order to appeal to the majority of nonreligious voters, save office, and reflect their own policy preferences. Therefore, we propose:

Expectation 3a: If an MP is actively engaged in a religious organization, he/she will not politicize morality issues in parliament.

Expectation 3b: If an MP is not actively engaged in a religious organization, he/she will politicize morality issues in parliament and propose permissive reform proposals. 


\section{RESEARCH DESIGN}

In order to analyze the foundations of the religious-secular party cleavage through a fresh, micro-level perspective, the study takes a closer look at the German Bundestag and the behavior of its members, specifically their politicization behavior with regard to morality policies. Three features make Germany a good case for contrasting the influence of the different facets of religion. First, Germany can be classified as a typical representative of the religious world. Its Christian Democratic parties compete with social-liberal parties for political power, thus meeting the strong requirement for the existence of a religious-secular conflict and the significant influence of religion on morality politics. Second, Germany is a country with two strong religious denominations (Catholicism and Protestantism), allowing for a more multifaceted perspective on religion. Third, Germany is an interesting case because Christian Democratic parties are still very successful compared to their counterparts in other European countries, where religious parties have experienced serious electoral defeats (Bale and Krouwel 2013).

The study focuses on three morality policies: gay marriage, prostitution policy, and embryonic stem cell research. All three issues were discussed during the $14^{\text {th }}$ legislative term (1998-2002) of the Bundestag and touch on different value-loaded struggles related to gender, minority rights, selfdetermination, and life protection. Moreover, all three issues were regulated with a comparably restrictive approach at that time (Knill et al. 2015). In addition, the issues also differ in terms of how they affect internal party heterogeneity. While party discipline was in working order for gay marriage and prostitution policy, it was abandoned in the agendasetting process related to embryonic protection policy, as neither the Christian Democratic nor the secular parties could agree internally on a common position. Consequently, the policy selection offers a strong test for exploring the religious fundament of a religious-secular party cleavage.

The study follows a two-fold approach of analysis: First, we conduct a descriptive assessment of the use of different instruments of issue politicization (motions and bills) by party. Second, we focus on issue politicization via bills. In detail, we assess whether an MP contributes to initiate bills on morality issues or intentionally avoids such an initiation process. ${ }^{6}$ In addition, we analyze the content of the bills and sort them according to their regulatory restrictiveness. The categorization of bills follows other scholars in the field that distinguishes between different policy paradigms (Euchner 2015b; Fink 2007; Preidel 2015). ${ }^{7}$ In the 
field of same-sex partnership rights, we differentiate between a regulatory model of cohabitation and a model of registered partnerships. With regard to prostitution policy, the policy paradigms of "limited recognition" and "full recognition" are taken into account. And in the field of embryonic stem cell research, three different types of bills are distinguished: a model of prohibition, a model specifying key dates, and a model favoring an import solution. We use regression analysis to investigate whether MPs' politicization behavior still follows the traditional religious divide between Catholics and non-Catholics. For each policy field, a multinomial variable is created that covers as categories the different reform proposals that were posed and the option "none" - with the latter covering the option of initiating none of the bills. Thus, we created a novel dataset which includes personal characteristics of MPs as well as the type and number of initiatives they propose during the $14^{\text {th }}$ legislative period (see for some descriptive statistics of the dependent and the independent variable Table A1 in the online Appendix).

The personal characteristics concerning individual religious denomination and engagement are the independent variables. The biographical data of the MPs, published on the homepage of the German Bundestag, serve as the data source (Preidel 2016). The first explanatory variable is a dummy and captures affiliation to a religious party, that is, being member of the CDU or CSU. The second independent variable covers, separately, the "religious denomination" of the MP, that is, being Catholic, Protestant, or unaffiliated. "Religious engagement" is an indicator for individual religiosity, capturing whether the MP is or was in the past an active member of a Christian organization, for example, by engaging in one of the Catholic organizations Kolpingwerk or Caritas or in the Protestant organization Diakonie. Different control variables are considered for modelling the data: being resident of East Germany, age, gender, and possession of an academic degree. These factors not only confound with the religious effects but also determine the party affiliation.

For every policy field, we estimate two separate multinomial logistic regression models, given the nominal structure of the dependent variables. Model 1 incorporates the affiliation to a religious party and the controls, testing the validity of Expectations $1 \mathrm{a}$ and $1 \mathrm{~b}$. In addition, we control for the specific party affiliation because, on the one hand, the individual behavior of deputies in parliamentary systems is characterized by strong party discipline (Carey 2009); on the other hand, MPs are socialized through their party affiliation in the long run (Kam 2011). For this purpose, we estimate clustered standard errors considering the five 
different parliamentary party groups in the German Bundestag: the Christian Democratic Union (CDU/CSU), the Social Democrats (SPD), the Liberals (FDP), the Green Party (Bündnis90/Die Grünen) and the Left Party (Die Linke).

Model 2 tests the effect of religious denomination and engagement, covering all individual controls in addition to the two relevant independent variables (cf., Expectations $2 \mathrm{a}$ and $2 \mathrm{~b}$ as well as Expectations $3 \mathrm{a}$ and $3 b$ ). This second model does not aim to investigate whether political parties matter, but whether the variables of religious denomination or religiosity unify politicization coalitions. Considering the crucial role of parties in forming coalitions in the parliamentary process and socializing members, we again estimate clustered standard errors, as in Model 1.

If we were to integrate party affiliation as a nominal variable, that variable would explain all variation in the case of gay marriage and prostitution policy and most of the variation with regard to the politicization of stem cell policy, where party discipline was suspended (Baumann, Debus, and Müller 2013). This relationship results not only from mechanisms of party socialization (Kam 2011), but also from the personal decision to join a specific political party. Empirical studies investigating such decisions find that individuals choose a party that represents their preferences for their most salient policy issue (Klein 2006; Laux 2011; Whiteley et al. 1994). Morality issues represent such topics of high salience because they touch on first principles and speak to people's belief system (Mooney 2001). Therefore, we suggest that the decision to join a specific party follows the same logic as individual policy activity in the political arena. This proposition is supported by an extra multicollinearity analysis, which shows that Cramer's $V$ between party affiliation and individual politicization in the three fields under study varies on a high level, among 0.45 and 1.00. Consequently, integrating party affiliation as an explanatory variable would prevent us from being able to unpack the "black box" of monolithic political parties. As such, controlling for the specific party affiliation with clustered standard errors is the most appropriate strategy.

For the interpretation of the estimation results, the marginal effects of the three main explanatory factors are calculated and presented in Figures 3, 5, and 7. The specific estimation results of the multinomial logistic regression models are reported in the online Appendix (see, Tables A2-A4). 


\section{THE RELIGIOUS-SECULAR CLEAVAGE IN GERMAN MORALITY POLICIES}

\section{Politicization in Gay Marriage Law}

Discussion of gay marriage centers around debates regarding discrimination against homosexuals. The latter topic has been on the German parliamentary agenda since the 1970 s, when reforms related to this issue were first adopted. The question of same-sex partnership rights came up in the early 1990s, when discrimination against single homosexuals was largely abolished. In that time, the gay rights movement started to organize itself in a more professional way and gained increased societal salience via smaller demonstrations (Kollman 2013). Consequently, gay marriage entered the electoral programs of small secular parties and, later, the SPD. In the national election of 1998, all three secular parties (the SPD, the Green Party, and the FDP) called for gay rights-related reforms in their electoral programs. The Green Party discussed the topic most extensively (Euchner 2015a) and demanded far-reaching rights for same-sex couples, including, for instance, the formal recognition of same-sex partnerships and equal rights in terms of family benefits. As Figure 2 shows, these demands were repeated in various motions and bills, resulting in highly charged debates. In 2000 in particular, a large number of bills and motions were proposed by all of the secular parties.

After a long bargaining process between the two coalition partners in government, the SPD and the Green Party, the common parliamentary
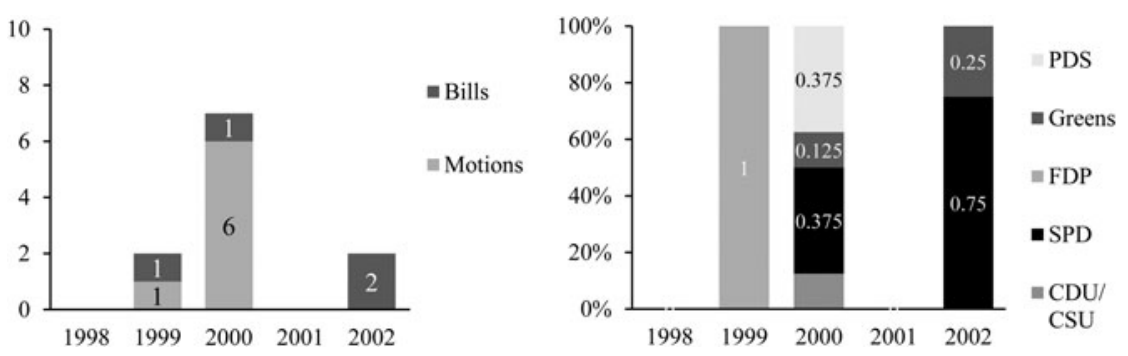

FIGURE 2. Politicization of gay marriage policy across political instruments and parties (German Bundestag, 1998-2002). Note: The first graph displays the absolute number of politicization instruments. The second graph illustrates the extent to which the different parties were involved in politicizing the issue. Data source: German Bundestag. 

a) Religious vs secular party member
b) Catholic vs Protestant
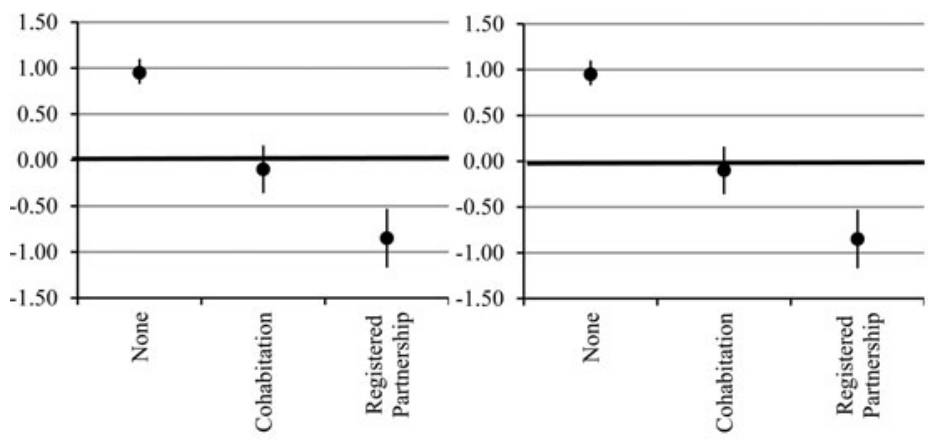

c) Religious vs non-religious

d) Religious Catholic vs. Protestant
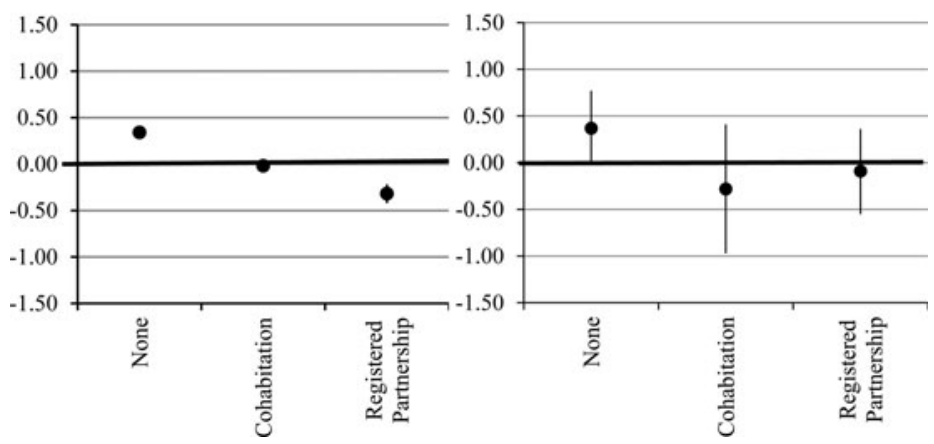

FIGURE 3. Marginal effects of the determinants of initiative behavior in gay marriage policy. Note: Marginal effects (95\%-confidence interval), calculated on the base of the multinomial logistic regression models. Other variables are fixed at their means. $N($ Total $)=667, N($ Cohabitation $)=43, N($ Registered Partnership $)=343, N($ None $)=281$. Data source: German Bundestag.

group joined together to submit a proposal for registered same-sex partnerships (Preidel 2015). It was the most permissive reform proposal, although it refrained from addressing discrimination in terms of adoption, income taxation or family benefits for civil services given the SPD's still reluctant position regarding these issues (Euchner 2015a). In a second bill, the Liberal Party proposed a model of cohabitation for same-sex couples, coinciding with even fewer rights and a more clear-cut separation from the institution of marriage.

The Christian Democrats (CDU/CSU) and the PDS refrained from proposing any initiative. The fact that the main religious party did not seek to 
increase the salience of same-sex partnership rights, while secular parties drew attention to the topic is also reflected in the estimation results of the multinomial regression model. Figure $3 \mathrm{a}$ plots the marginal effects of being a member of one of the Christian Democratic parties and initiating any bill. In contrast to an MP of a secular party, an average Christian Democratic deputy systematically preferred to ignore the issue (see "none" category). In numerical terms, the analysis shows that the discrete predicted probability of abstaining from politicizing the issue ("none" category) increased by 95 percentage points for members of a Christian Democratic party instead of a secular party, holding all other variables constant at their mean. Conversely, the discrete predicted probability of initiating a bill on registered partnership models decreased by 85 percentage points when changing the affiliation from a secular to a religious party, holding all other factors constant at their mean. These results support the argument of Engeli, Green-Pedersen, and Larsen (2012) and, therefore, Expectations 1a and 1b.

But what happens when we examine the influence of religion in more detail? Does the divide between members of Christian Democratic parties and secular parties found on the traditional cleavage between Catholics and non-Catholics and thus, on a denominational divide? The estimated regression model indicates that being Catholic appears to be important for the politicization strategy of single deputies, supporting Expectations $2 \mathrm{a}$ and $2 \mathrm{~b}$. The marginal effect plot in Figure $3 \mathrm{~b}$ shows that deputies affiliated with the Catholic Church were more likely to refrain from politicizing the issue via new initiatives than Protestants. This effect was not only apparent in comparison to Protestant MPs, but also relative to deputies that were non-affiliated to one of the Christian churches. Holding all other factors constant at their mean, the discrete predicted probability of refraining from issue politicization increased by 34 percentage points when the religious affiliation of a MP changed from Protestant to Catholic. Additionally, the discrete predicted probability of opting for a registered partnership model decreased by 32 percentage points, holding all other factors constant at their mean.

These results do not indicate that active church members are more likely to follow this strategy than religiously inactive MPs; those results lack clear-cut statistical significance (see Model 2 in Table A2 in the online Appendix and the margin plots in Figure 3c). As religious engagement often co-varies with religious denomination, we estimated an interaction term, confirming that religious Catholics are more likely to abstain from issue politicization than Protestants (see Model 3 in Table A2 in the 
online Appendix and Figure 3d). Religious Protestants, however, do not behave uniformly with regard to the politicization of same-sex partnership rights in contrast to non-religious Protestants. In other words, the religiosity of MPs interacts systematically only with one specific religious denomination. Thus, the denominational divide remains a strong significant factor that substantially impacts MPs' politicization behavior. Specifically, the discrete predicted probability of refraining from morality politicization increased by 28 percentage points for a denominational change from Protestant to Catholic. These results suggest that the party cleavage between Christian Democratic and secular parties founds mainly on the traditional denominational divide, while a conflict between religious and non-religious deputies is not so much an independent factor, but one that interacts with a specific religious denomination (i.e., mainly with Catholicism).

\section{Politicization in Prostitution Policy}

Like gay marriage, the topic of prostitution also reached the governmental agenda in the $14^{\text {th }}$ legislative period. In previous years, the SPD and especially the Green and the PDS pressured the Christian Democratic-liberal Kohl government to adopt comprehensive reform proposals by different parliamentary initiatives. A key demand was to abolish the legal "immorality" of prostitution, with proponents of this reform arguing that such juridical pronouncement of immorality imposed serious disadvantages for prostitutes, making it extremely difficult to offer sexual services under safe conditions. Prostitutes could not be employed legally and sue their clients for non-payment, but still had to pay taxes, thus producing a discrepancy between societal reality and law (Euchner and Knill 2015). During the national election of 1998 , all secular parties prioritized the topic in their party manifestos and increased attention on the topic via various bills and motions during the legislative term (see Figure 4). The Christian Democrats were active only once: in 2001, the main religious party submitted a motion in response to the governmental bill.

At the end of the legislative term, two bills of the secular parties made their way onto the parliamentary agenda. The government coalition between SPD and Greens presented the first legislative proposal, called "Limited recognition model." The PDS submitted a second proposal called "Full recognition model," which included more far-reaching rights for prostitutes (e.g., abolishing locational restrictions and the 

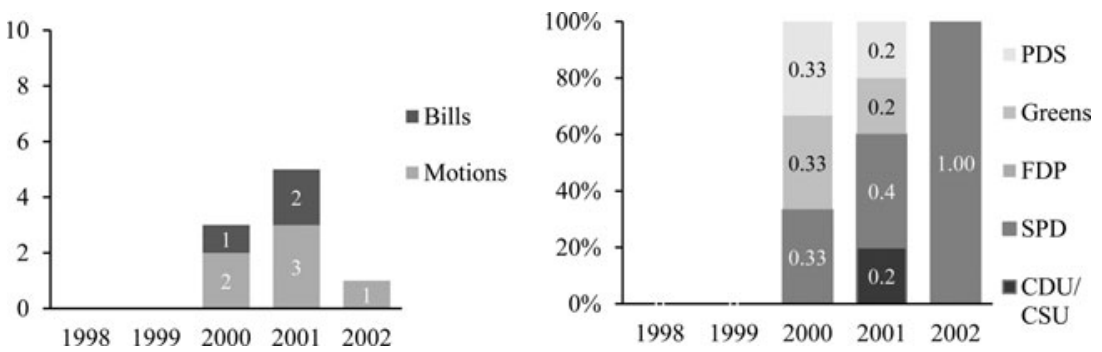

FIGURE 4. Politicization of prostitution policy across political instruments and parties (German Bundestag, 1998-2002). Note: The first graph displays the absolute number of politicization instruments. The second graph illustrates the extent to which the different parties were involved in politicizing the issue. Data source: German Bundestag.

prohibition of advertisement). Moreover, the PDS's proposal subsumed concrete suggestions regarding implementation of the policy at the regional level. Both the Christian Democrats and the FDP refrained from submitting any legislative initiative (see Figure 4). The regression analysis of individual politicization behavior reflects this picture: the main religious parties avoided to increased issue attention, while the main secular parties followed the reverse approach. Figure 5a plots the marginal effects of being a member of the Christian Democratic parties, while the other factors are fixed at their mean. ${ }^{8}$ On average, Christian Democratic MPs had a significantly higher probability of being passive, while a member of one of the secular parties was significantly more likely to initiate a proposal. More detailed analyses show that discrete predicted probabilities of abstaining from politicizing the issue ("none" category) increased by 89 percentage points when changing party membership from secular parties to a Christian Democratic party, holding all other variables constant at their mean. Conversely, the same change reduces the discrete predicted probability of demanding limited recognition for sex workers by 85 percentage points, when holding all other factors constant at their mean. Thus, at first glance and in accordance with Expectations 1a and $1 \mathrm{~b}$, we discover a divide between Christian Democratic MPs and MPs of secular parties in terms of issue politicization, in keeping with Engeli, Green-Pedersen, and Larsen's (2012) propositions.

However, how does the picture shift when we consider a more multifaceted concept of religion, focusing on the denominational divide and religiosity? Figure $5 \mathrm{~b}$ illustrates that the religious denomination of deputies has a strong and significant effect on their politicization behavior. Being 
a) Religious vs secular party member

b) Catholic vs Protestant
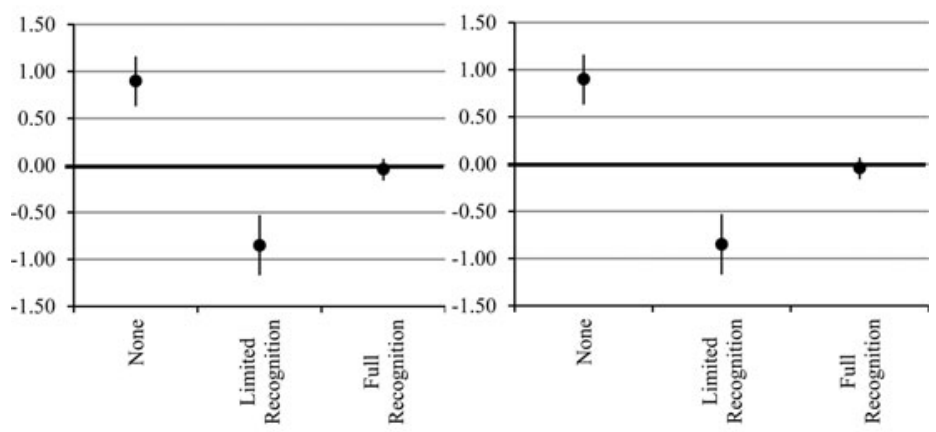

c) Religious vs non-religious

d) Religious Catholic vs. Protestant
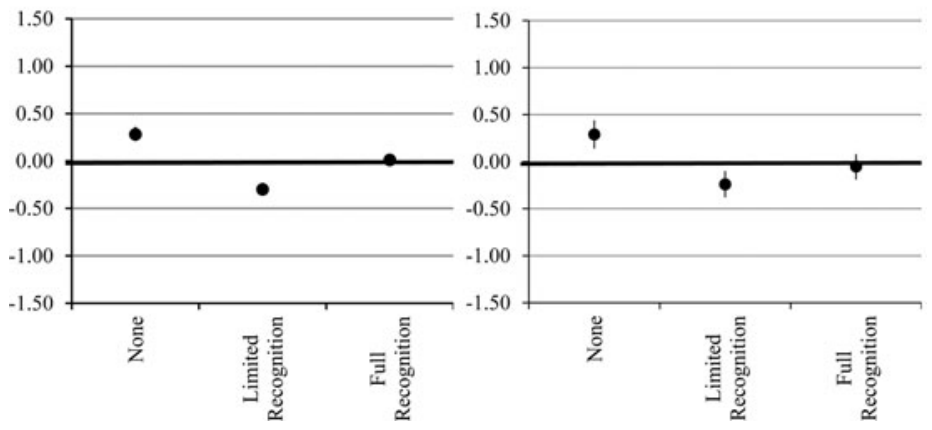

FIGURE 5. Marginal effects of the determinants of initiative behavior in prostitution policy. Note: Marginal effects (95\%-confidence interval), calculated on the base of the multinomial logistic regression models. Other variables are fixed at their means. Data source: German Bundestag.

affiliated with the Catholic Church coincided with a much higher likelihood of not politicizing prostitution policy, while Protestants were more likely to actively politicize the issue by co-sponsoring proposals for the limited recognition of sex workers. The latter also holds for non-affiliated MPs. The discrete predicted probability of tabling no initiatives on prostitution policy (or "none") increased by 28 percentage points when changing the religious affiliation from non-Catholic to Catholic. Finally, the effect of religious engagement is less pronounced and not statistically significant (see Figure 5c and Table A3 in the online Appendix).

As discussed above, religiosity often interacts with religious denomination. Also in the field of prostitution policy, the interaction term between 
Catholicism and religiosity is statistically significant and negative (see Model 3 in Table A3 in the online Appendix). Thus, religious Catholics were more likely to ignore the issue of prostitution policy compared to Protestants. The discrete predicted probability of non-politicization increased by 28 percentage points for members of the Catholic Church who are religious, holding all other factors constant. However, the religiosity of Protestant MPs failed to interact systematically with parliamentary behavior. As a result, Catholic denomination appears to have a systematic effect on the politicization strategies of single deputies, supporting Expectations $2 \mathrm{a}$ and $2 \mathrm{~b}$. These results indicate that the party cleavage in morality politics between Christian Democrats and deputies of secular parties founds mainly on the traditional divide between Catholics and non-Catholics, while religiosity is a secondary factor interacting positively only with Catholicism.

\section{Politicization in Embryonic Protection Policy}

The issue of embryonic protection came on the parliamentary agenda during the $14^{\text {th }}$ legislative period of the German Bundestag in reaction to new developments in biomedical research (Nebel 2015). On the one hand, a research team successfully extracted embryonic stem cells from a blastocyst, opening new possibilities to use these cells for research and medical treatment. On the other hand, new diagnostic methods were developed for checking the genetic disposition of embryos before implantation. In Germany, the Embryonenschutzgesetz (Embryonic Protection Act) of 1990 prohibited both techniques (Rothmayr and Ramjoué 2004). Due to increasing societal demand for policy change, the issue soon turned up on the political agenda. Figure 6 illustrates the politicization of embryonic protection policy across political instruments (bills and motions) and parties between 1998 and 2002. In line with the expectations of Engeli, Green-Pedersen, and Larsen (2012), secular parties put this issue on the agenda. Interestingly, however, it was primarily smaller parties that were the driving forces of the debate, while the major parties struggled with intra-party heterogeneity and thus remained relatively passive in promoting common motions or bills on the issue (Rothmayr and Ramjoué 2004).

Although the issue touched traditional Christian values concerning the sanctity of life, MPs within neither the social-green government nor the single catch-all parties - SPD and CDU/CSU - were able to agree on a common position. While the discussion on pre-genetic diagnosis 

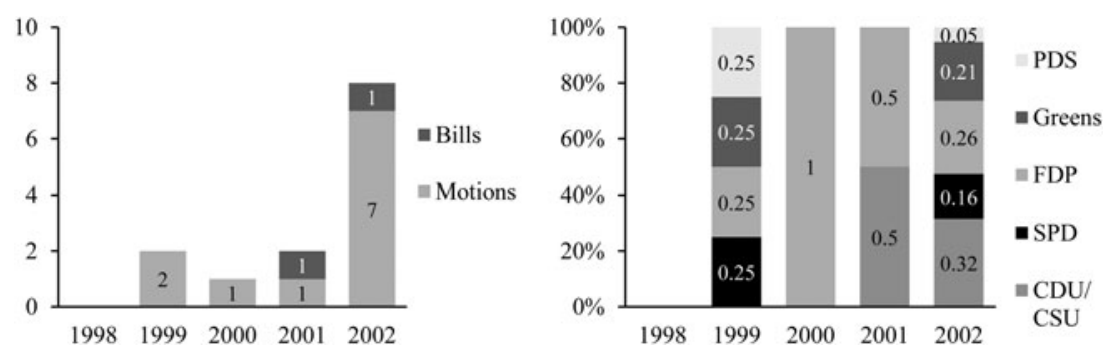

FIGURE 6. Politicization of embryonic protection policy across political instruments and parties (German Bundestag, 1998-2002). Note: The first graph displays the absolute number of politicization instruments. The second graph illustrates the extent to which the different parties were involved in politicizing the issue. Data source: German Bundestag.

fizzled out, the debate on the usage of embryonic stem cells in biomedicine was framed as an issue of conscience, involving the suspension of party lines and the elaboration of policy proposals across parties. In that stage, some Christian Democratic MPs abandoned their strategy of passivity and were actively involved in politicizing the topic via bills. In total, three bills were proposed. While one group proposed to keep the status quo of prohibition, a second coalition of MPs suggested the import of cell lines for research purposes. The third proposal defended a compromise solution, permitting the import of stem cells according to strict conditions. The primary requirement was compliance to a key date of January 2002 - specifically, the embryo had to be produced abroad prior to this date (Nebel 2015).

In sum, a clear divide between MPs of Christian Democratic and secular parties is absent in the politicization of embryonic stem cell research in Germany. The regression analysis of individual co-sponsorship behavior illustrates this in more detail. Figure 7a provides a graphical interpretation of these results and plots the marginal effects of being a member of Christian Democratic parties on the (non-)sponsorship of one of the initiatives. Christian Democratic MPs did not remain inactive. In fact, they had a significantly higher probability of politicizing the topic. Many Christian Democratic MPs co-sponsored a bill that demands the total prohibition of embryonic stem cell research. Changing from a secular party to one of the religious parties even decreased the discrete predicted probability of the "none" option by 4 percentage points. It means, Christian Democratic MPs had a slightly higher probability to proposal a bill and hence, to politicize the issue. These findings contradict Expectation 1a. 
a) Religious vs secular party member

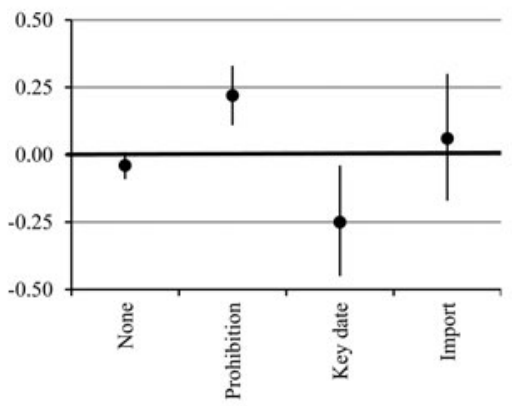

c) Religious vs non-religious

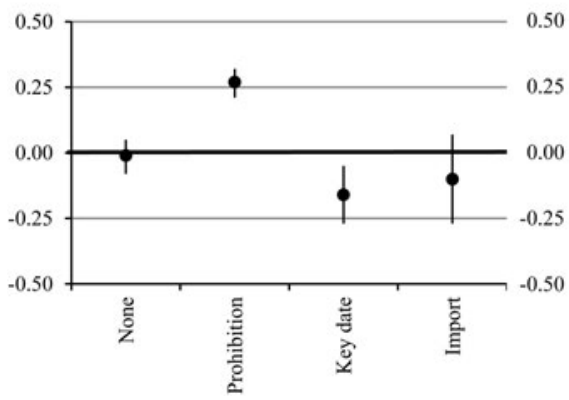

b) Catholic vs Protestant

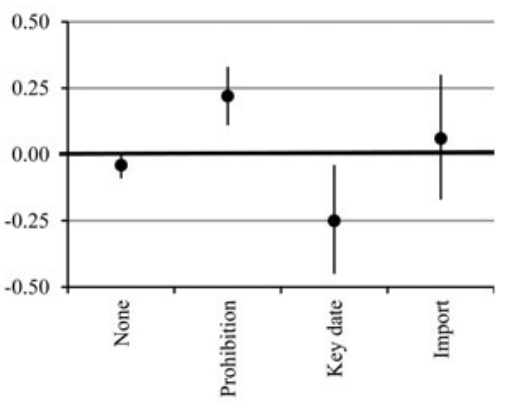

d) Religious Catholic vs. Protestant

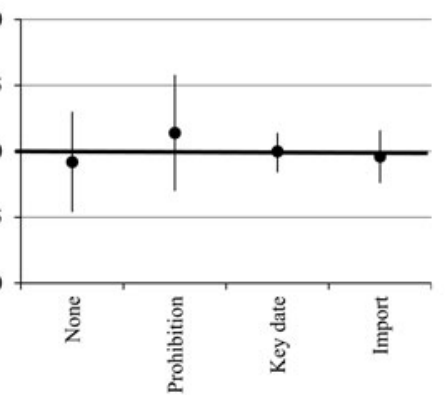

FIGURE 7. Marginal effects of the determinants of initiative behavior in embryonic protection policy. Note: Marginal effects (95\%-confidence interval), calculated on the base of the multinomial logistic regression models. Other variables are fixed at their means. $N($ Total $)=664, N($ Prohibition $)=232, N$ $($ Import with key date $)=188, N($ Import $)=86, N($ None $)=158$. Data source: German Bundestag.

These insights raise questions about the underlying religious fundament of the cleavage between religious and secular party members. Which religious aspects drive individual politicization behavior? The results of the two multinomial regression models, presented in the marginal effects plots in Figure $7 \mathrm{~b}$ and $7 \mathrm{c}$, shed light on this question. ${ }^{9}$ The model indicates that Catholicism is the dividing force of the engagement of Christian Democratic party members and religiosity turns out to be an additional dimension.

Figure $7 \mathrm{~b}$ shows that Catholics are more likely to advocate for the protection of the unborn life. Therefore, the main divide is between Catholics 
and non-Catholics, supporting only Expectation 2b. An additional finding is that Protestant MPs are active but propose more permissive bills than Catholic MPs. The divide between religiously engaged and non-engaged MPs is less pronounced, as Figure 7c shows, but we also observe significant distinctions that contradict Expectations $3 \mathrm{a}$ and $3 \mathrm{~b}$. While active church members tend to co-sponsor any of the proposals, non-engaged MPs tend to refrain from drawing attention to the issue. In contrast to the previous analyses, however, religiosity does not interact systematically with Catholicism (see Figure $7 \mathrm{~d}$ and Model 3 in Table A4 in the online Appendix). Religious Catholics do not behave differently than Protestants and religious Protestants do not behave differently than nonreligious Protestants. ${ }^{10}$

In sum, the suspension of party discipline during the policy formulation process of morality issues stimulates a different parliamentary behavior of MPs belonging to secular or religious political parties. As soon as party discipline is suspended and collective party strategies no longer structure parliamentary behavior, several Christian Democrats cease to follow the strategy of not politicizing morality issues. Instead, they - and Catholic MPs in particular - actively lobby for restrictive regulation by formulating corresponding initiatives. However, this behavior is not systematically related with the level of religiosity of Catholic MPs. It means that religious MPs and particularly religious Catholics are not systematically more active or passive with regard to the politicization of morality issues. Consequently, only when party competition is in working order, secular parties and their members are able to play off religious counterparts by an issue competition logic that integrates policy-, vote-, and officeseeking aims.

\section{CONCLUSION AND DISCUSSION}

This study examines whether parliamentary party competition on morality policies in Germany aligns with the cleavage between Christian Democratic and secular parties. We rely on the idea of issue competition and assume that party competition in parliament can be accessed through the examination of politicization patterns of individual MPs (i.e., number and type of suggested motions and bills). In doing so, we seek to open the "black box" of political parties - regularly seen as monolith collective actors - and explore the religious-secular party cleavage in the German parliament from a new, micro-level perspective. 
Our findings reveal that the conflict between Christian Democratic and secular parties is still grounded in the historical divide between Catholic and non-Catholics across all three explored morality policies. Catholics are less engaged in the agenda-setting stage. Only under the suspension of party discipline, Catholics are likely to take a public stance on morality policies. These initiatives suggest, however, rather restrictive policy solutions. Moreover, the religiosity of MPs shapes politicization patterns, though less so than does Catholicism. Only in two out of three morality policies, the religiosity of MPs seems to shape politicization behavior of MPs (for a summary of all results see Table 1). Moreover, a more detailed analysis shows that religiosity interacts positively with Catholicism only with regard to two morality policies (same-sex partnership rights and prostitution policy). This suggests that religious Catholics have an increased predicted probability of not politicizing morality policies compared to secular non-Catholics. The religiosity of Protestant MPs does not systematically influence their politicization behavior - even when party discipline is dissolved. Hence, Protestant MPs (even if they are religious) stand somewhere in between value-conservative Catholics and liberal, non-affiliated MPs. This finding might be the product of comparably vague policy positions of the Protestant Church in Germany and less hierarchical structures, which offer room of interpretation for their members.

By investigating religious-secular party cleavages in the parliamentary arena from a micro-level perspective and focusing on the concept of issue competition, we demonstrate the value of examining political parties not as unitary actors but as groups of individual MPs with diverse personal characteristics. Specifically, electoral studies on the

Table 1. Summary of results

\begin{tabular}{lcccc}
\hline & $\begin{array}{c}\text { Morality } \\
\text { policies } \\
\text { general }\end{array}$ & $\begin{array}{c}\text { Gay } \\
\text { marriage }\end{array}$ & $\begin{array}{c}\text { Prostitution } \\
\text { policy }\end{array}$ & $\begin{array}{c}\text { Embryonic } \\
\text { protection } \\
\text { policy }\end{array}$ \\
\hline $\begin{array}{l}\text { Hypotheses } \\
\begin{array}{l}\text { Religious vs secular party } \\
\text { member }\end{array}\end{array}$ & $(+)$ & + & + & - \\
$\begin{array}{l}\text { 2. Catholic vs non-Catholic } \\
\begin{array}{l}\text { 3. Religious engaged vs non- } \\
\text { religious }\end{array}\end{array}$ & + & + & $(+)$ & + \\
\end{tabular}

Source: Own compilation. $+=$ full support; $(+)=$ limited support; $\pm=$ mixed evidence; $-=$ no support. 
transformation of the religious cleavage find that the traditional denominational divide has decreased salience and that the distinction between the religious and non-religious is increasingly relevant, yet these claims do not hold for the parliamentary arena in the German context. Our findings suggest that the described changes of Christian Democracy throughout Europe have not provoked pronounced changes in the societal foundations of the party conflict; instead, the denominational divide is still relevant at least in Germany. Still, it should be noted that Catholicism itself is undergoing change, as more and more people question traditional creeds and accept more heterogeneity (Willems 2007).

This study highlights several opportunities for future research. First, the analysis of party competition in the German Bundestag does involve some particularities, such as the existence of two equally strong churches, restricting the generalization of results. Therefore, we suggest re-evaluating our hypotheses in additional countries with two or more religious denominations (e.g., the Netherlands or Switzerland), with different religious denominations (e.g., Orthodox, Evangelicals), as well as in single-religion countries. Moreover, it is Germany's specific multi-party system and the large size of the two mass parties that makes the politicization of morality issues a challenge; in other countries, minor religious parties can actually strengthen their profile by politicizing morality issues (Timmermans and Breeman 2012). Future research could investigate how highly fragmented party systems with many small parties (e.g., Denmark, Belgium) deal with similar issues. Second, it would be interesting to apply this micro-level approach of religious-secular cleavages to other issues related with religious values, such as family policy, religious education, or immigration policy. This, in addition to a longer time horizon, would be a valid and creative way to explore the relative stability versus change of the religious-secular cleavage among political elites against the backdrop of secularization.

\section{NOTES}

1. Many countries around the world are experiencing decreased levels of religiosity (Fox 2015). However, in some countries such as the United States, religion does not lose relevance but instead drives increased polarization among political forces (Layman and Weaver 2016).

2. The terms "morality policies" and "value-loaded policies" are used interchangeably.

3. In contrast to the traditional party competition literature, Budge and Farlie (1983) argue that political parties compete not only in terms of specific issue positions, but also in terms of how issues are politicized and/or emphasized. The idea of issue competition is the center of the Comparative Party Manifesto Project that was subsequently initiated by Budge and Farlies. The project compiles an enormous dataset that captures the relative salience of different issues across 
party manifestos. This further suggests that the scholars are mainly interested in the attention political parties dedicate to certain issues, whereas parties' specific issue positions are secondary.

4. In line with Engeli, Green-Pedersen, and Larsen (2012), we assume that morality policies provoke party conflicts because the German party system developed along a religious-secular conflict line within German society, which can, therefore, be classified as part of the "religious world."

5. The study proposes parallel causal paths for the macro- and micro-levels. It means, at the macrolevel, we expect a positive relationship between a religious-secular party cleavage and the parliamentary salience of morality policies. At the micro-level, we expect that certain religious values of MPs shape the co-sponsorship of legislative bills and, hence, the general salience of morality policies. However, in contrast to Coleman (2000), we do not aim to explore the two causal mechanisms that link the macro- and micro-level.

6. One might discuss whether the number of initiated bills (respectively the fact of initiation) is an appropriate indicator to assess issue politicization because about $35 \mathrm{MPs}$ are required to propose a bill in the German Bundestag (at least 5\% of all MPs). As a result, the MP is not independent in his/her decision to politicize an issue. On the other hand, many studies use the same indicator to measure issue politicization or rely on indicators having the same deficit (e.g., motions, party manifestos). Moreover, bills provoke larger public and political attention because they are presented in one plenary session and discussed in another plenary session in Germany. Written questions, for instance, can be proposed independently from the support of other MPs but they coincide with much lower levels of issue attention and hence, can also be questioned in terms of their appropriateness for assessing issue politicization. Finally, the inclusion of a morality issues (embryonic stem cell research) for which party discipline was abandoned in the initiation stage allows to control for any unintended effect caused by the selection of parliamentary instruments.

7. If one of the prominent policy paradigms (e.g., "same-sex marriage" or "abolitionism") is not considered in any of the bills, then the bills are not part of the analysis.

8. Table A3 in the online Appendix depicts the result of the regression analysis.

9. Table A4 in the online Appendix depicts the result of the regression analysis.

10. When estimating an additional model with an interaction term between party affiliation and Catholicism, we observe an increased and significant probability of Catholics being member of the CDU to opt for a prohibition model compared to Catholics being member in any other party or compared to non-Catholics.

\section{SUPPLEMENTARY MATERIALS}

\section{To view supplementary material for this article, please visit https://doi.org/ $10.1017 / \mathrm{S} 1755048317000694$.}

\section{REFERENCES}

Asal, Victor, Udi Sommer, and Paul G. Harwood. 2013. "Original Sin.” Comparative Political Studies 46:320-351.

Bale, Tim, and André Krouwel. 2013. “Down but Not Out: A Comparison of Germany's CDU/CSU with Christian Democratic Parties in Austria, Belgium, Italy and the Netherlands." German Politics 22:16-45.

Baumann, Markus, Marc Debus, and Jochen Müller. 2013. "Das legislative Verhalten von Bundestagsabgeordneten zwischen persönlichen Charakteristika, Wahlkreisinteressen und Parteilinie: Eine Untersuchung am Beispiel der Auseinandersetzung um die Präimplantationsdiagnostik (The Legislative Behavior of German Members of Parliament as Question of Personal Traits, Interests of the Constituency or Party Preferences: an Exemplary Examination of the Regulation of Pre-Implantation Genetic Diagnosis)." Zeitschrift für Politikwissenschaft 23:177-211. 
Van Der Brug, Wouter, Sara B. Hobolt, and Claes H. de Vreese. 2009. "Religion and Party Choice in Europe." West European Politics 32:1266-1283.

Budge, Ian, and Dennis Farlie. 1983. "Party Competition - Selective Emphasis or Direct Confrontation? An Alternative View with Data." In Western European Party Systems: Continuity \& Change, eds. Daalder, Hans, and Peter Mair. Beverly Hills, CA: Sage Publications, 276-305.

Carey, John M. 2009. "Legislative Voting and Accountability." In Cambridge Studies in Comparative Politics. New York, NY: Cambridge University Press.

Clemens, Clay. 2009. "Modernisation or Disorientation?: Policy Change in Merkel's CDU." German Politics 18:121-139.

Coleman, James S. 2000. Foundations of Social Theory. Cambridge, MA: Belknap Press of Harvard University Press.

Debus, Marc, and Jochen Müller. 2013. "The Programmatic Development of CDU and CSU since Reunification: Incentives and Constraints for Changing Policy Positions in the German Multi-Level System." German Politics 22:151-171.

Elff, Martin. 2013. "Social Divisions and Political Choices in Germany, 1980-2006." In Political Choice Matters: Explaining the Strength of Class and Religious Cleavages in Cross-National Perspective, eds. Evans, Geoffrey, and De Graaf, Nan Dirk. Oxford: Oxford University Press, 277-308.

Engeli, Isabelle, Christoffer Green-Pedersen, and Lars T. Larsen, eds. 2012. Morality Politics in Western Europe: Parties, Agendas and Policy Choices. Basingstoke: Palgrave Macmillan.

Euchner, Eva-Maria. 2015a. "Politics of Dilemma: Coalition Considerations and Political Conflicts on Morality Policies in Germany and Spain." Ph.D. Diss. Universität Konstanz.

Euchner, Eva-Maria. 2015b. "Prostitutionsregulierung: Politische Einigung zulasten der Implementation (Prostitution Policy: Political Agreement at the Expense of Policy Implementation)." In Moralpolitik in Deutschland (Morality Policy-Making in Germany), eds. Knill, Christoph, Stephan Heichel, Caroline Preidel, and Kerstin Nebel. Wiesbaden: VS-Verlag, 107-26.

Euchner, Eva-Maria, and Christoph Knill. 2015. "Sin, Unavoidable Evil or Recognized Profession? Prostitution Regulation Between Authority and Permissiveness." In On the Road to Permissiveness? Change and Convergence of Moral Regulation in Europe, eds. Knill, Christoph, Christian Adam, and Steffen Hurka. Oxford: Oxford University Press, 129-157.

Evans, Geoffrey, ed. 1999. The End of Class Politics. Class Voting in Comparative Context. Oxford: Oxford University Press.

Fink, S. 2008. "Politics as Usual or Bringing Religion Back In?: The Influence of Parties, Institutions, Economic Interests, and Religion on Embryo Research Laws." Comparative Political Studies 41:1631-156.

Fink, Simon. 2007. "Ein deutscher Sonderweg?: Die deutsche Embryonenforschungspolitik im Link international vergleichender Daten (A German Sonderweg? The German Policy on Embryo Research in Comparative Perspective)." Leviathan 35:107-128.

Fox, Jonathan. 2015. Political Secularism, Religion, and the State: A Time Series Analysis of Worldwide Data. Cambridge Studies in Social Theory, Religion and Politics. Cambridge: Cambridge University Press.

Heichel, Stephan, Christoph Knill, and Sophie Schmitt. 2013. "Public Policy Meets Morality: Conceptual and Theoretical Challenges in the Analysis of Morality Policy Change." Journal of European Public Policy 20:318-334.

Kalyvas, Stathis N., and Kees Van Kersbergen. 2010. "Christian Democracy." Annual Review of Political Science 13:183-209. 
Kam, Christopher J. 2011. Party Discipline and Parliamentary Politics. Cambridge: Cambridge University Press.

Klein, Markus. 2006. "Partizipation in politischen Parteien. Eine empirische Analyse des Mobilisierungspotenzials politischer Parteien sowie der Struktur innerparteilicher Partizipation in Deutschland (Participation in Political Parties. An Empirical Analysis of the Potential for Mobilization of Political Parties and the Structure of Participation within Parties in Germany)." Politische Vierteljahresschrift 47:35-61.

Knill, Christoph, Stephan Heichel, Caroline Preidel, and Kerstin Nebel, eds. 2015. Moralpolitik in Deutschland (Morality Policy-Making in Germany). Wiesbaden: VS-Verlag.

Knill, Christoph, Caroline Preidel, and Kerstin Nebel. 2014. "Brake Rather than Barrier: The Impact of the Catholic Church on Morality Policies in Western Europe." West European Politics 37:374-390.

Knutsen, Oddbjørn. 2004. "Religious Denomination and Party Choice in Western Europe: A Comparative Longitudinal Study from Eight Countries, 1970-97." International Political Science Review 25:97-128.

Kohut, Andrew. 2000. The Diminishing Divide: Religion's Changing Role in American Politics. Washington, DC: Brookings Institution Press.

Kollman, Kelly. 2013. The Same-Sex Unions Revolution in Western Democracies: International Norms and Domestic Policy Change. Manchester: Manchester University Press.

Kriesi, Hanspeter. 1998. "The Transformation of Cleavage Politics: The 1997 Stein Rokkan Lecture." European Journal of Political Research 33:165-185.

Kriesi, Hanspeter. 2010. "Restructuration of Partisan Politics and the Emergence of a New Cleavage Based on Values." West European Politics 33:673-685.

Laux, Annika. 2011. "Was motiviert Parteimitglieder zum Beitritt? (Which Motives Drive Party Membership?)" In Parteimitglieder in Deutschland. (Party Membership in Germany), eds. Spier, Tim, Markus Klein, Ulrich v. Alemann, Hanna Hoffmann, Annika Laux, Alexandra Nonnenmacher, and Katharina Rohrbach. Wiesbaden: VS Verlag für Sozialwissenschaften, 61-78.

Layman, Geoffrey C., and Christopher L. Weaver. 2016. "Religion and Secularism among American Party Activists." Politics and Religion 9:271-295.

Lipset, Seymour M., and Stein Rokkan, eds. 1967. Party Systems and Voter Alignments: Cross-National Perspectives. New York, NY: The Free Press.

Meier, Kenneth J., ed. 1994. The Politics of Sin: Drugs, Alcohol, and Public Policy. Armonk, NY: M.E. Sharpe.

Mooney, Christopher Z. 2001. "The Public Clash of Private Values." In Public Clash of Private Values: The Politics of Morality Policy., ed. Mooney, Christopher. New York, NY: Chatham House, 3-18.

Müller, Wolfgang, and Kaare Strøm, eds. 1999. Policy, Office, or Votes? How Political Parties in Western Europe Make Hard Decisions. Cambridge: Cambridge University Press.

Nebel, Kerstin. 2015. "Embryonale Stammzellforschungspolitik (Regulation of Embryonic Stem Cell Research)." In Moralpolitik in Deutschland (Morality PolicyMaking in Germany), eds. Knill, Christoph, Stephan Heichel, Caroline Preidel, and Kerstin Nebel. Wiesbaden: VS-Verlag, 89-107.

Preidel, Caroline. 2015. "Das zögerliche Jawort zur Homoehe (The 'hesitant Yes' to SameSex Marriage)." In Moralpolitik in Deutschland (Morality Policy-Making in Germany), eds. Knill, Christoph, Stephan Heichel, Caroline Preidel, and Kerstin Nebel. Wiesbaden: VS-Verlag, 147-65. 
Preidel, Caroline. 2016. "Zwischen Lebensschutz und Ökonomie: Parlamentarische Abstimmungen über den Embryonenschutz im Deutschen Bundestag (Protection of Life versus Economy: Legislative Voting on Embryonic Stem Cell Protection in the German Bundestag).” Ph.D. Diss. Universität Konstanz.

Rapp, Carolin, Richard Traunmüller, Markus Freitag, and Adrian Vatter. 2014. "Moral Politics: The Religious Factor in Referenda Voting." Politics and Religion 7:418-443.

Rothmayr, Christine, and Celina Ramjoué. 2004. "Germany: ART Policies as Embryo Protection." In Comparative Biomedical Policy: Governing Assisted Reproductive Technologies, eds. Bleiklie, Ivar, Malcolm L. Goggin, and Christine Rothmayr Allison. London: Routledge, 174-190.

Timmermans, Arco, and Gerard Breeman. 2012. "Morality Issues in the Netherlands: Coalition Politics under Pressure." In Morality Politics in Western Europe: Parties, Agendas and Policy Choices, eds. Engeli, Isabelle, Christoffer Green-Pedersen, and Lars T. Larsen. Basingstoke: Palgrave Macmillan, 35-61.

Van Kersbergen, Kees. 2008. "The Christian Democratic Phoenix and Modern Unsecular Politics." Party Politics 14:259-279.

Whiteley, Paul F., Patrick Seyd, Jeremy Richardson, and Paul Bissell. 1994. "Explaining Party Activism: The Case of the British Conservative Party." British Journal of Political Science 24:79.

Willems, Ulrich. 2007. "Kirchen.” In Interessenverbände in Deutschland, eds. Winter, Thomas, and Ulrich Willems. Wiesbaden: VS Verlag für Sozialwissenschaften, 316-340. 